( А. С. Морозов, К.Т.н., доцент, О. О. Гриценко, асистент, НТУУ «КПІ імені Ігоря Сікорського», Київ, Україна,

В. В. Швалагін, К.Х.н., наук. співробітник, Г. Я. Гродзюк, К.Х.н., мол. наук. співробітник, ІФХ НАН України, Київ, Україна

\title{
ВИГОТОВЛЕННЯ МАРКУВАНЬ РОЗУМНИХ ПАКОВАНЬ З ВИКОРИСТАННЯМ НАНОФОТОННИХ ФАРБОВИХ КОМПОЗИЦІЙ НА АЛЮМІНІЄВІЙ ФОЛЬЗІ ТРАФАРЕТНИМ СПОСОБОМ ДРУКУ
}

У статті досліджено можливість нанесення маркувань розумних паковань 3 нанофотонними елементами трафаретним способом друку на алюмінієву фольгу як перспективний пакувальний матеріал. Визначено вплив поверхневих характеристик алюмінієвої фольги, товщини шару фарби на відбитку і вмісту люмінесцентної складової

на оптичні характеристики одержуваних друкованих маркувань, що дає можливість виготовляти маркування розумних паковань 3 нанофотонними елементами з наперед заданими оптичними характеристиками трафаретним способом друку.

Ключові слова: трафаретний друк; фотолюмінесценція; розумні паковання; нанофотонні елементи; наночастинки ZnO.

\section{Постановка проблеми}

Розумні паковання набувають поширення у пакувальній індустрії завдяки низці таких переваг: вони можуть надавати актуальну інформацію про стан запакованого продукту шляхом реакції на речовини, що утворюються в результаті псування харчових продуктів [1, 2]. Таку реакцію можна відстежити візуально або інструментально і зробити висновок, чи $\epsilon$ продукт безпечним до споживання. При цьому відпадає потреба орієнтуватися лише на термін зберігання продукту, який не гарантує його збереження через можливий вплив нерекомендо- ваних умов зберігання, перезаморожування тощо. Розумні паковання збільшують безпечність споживання продукції та дозволяють практично уникнути отруєння неякісними (зіпсованими) харчовими продуктами, підвищуючи таким чином культуру споживання і привабливість цього продукту для споживача.

Нанофотонні елементи, а саме наночастинки $\mathrm{ZnO} / \mathrm{SiO}_{2}$, $є$ перспективними для використання при виготовленні активних елементів розумних паковань. Наночастинки $\mathrm{ZnO} / \mathrm{SiO}_{2}$ мають фотолюмінесцентні властивості, тобто світяться під

๑) $2016 \mathrm{p}$. 
дією ультрафіолетового (УФ) випромінювання [3], а в контакті з продуктами розпаду білкових і вуглеводних продуктів зменшують інтенсивність люмінесценції аж до повного її зникнення [4]. Маркування на їхній основі буде легко перевірити за допомогою УФ ламп, якими ко-ристуються для перевірки банкнот у торгових мережах.

Фольга як пакувальний матеріал, що широко застосовується у харчовій і пакувальній галузі, має перспективу використання для виготовлення розумних паковань. Алюмінієва фольга є нетоксичною, інертною, не надає харчовим продуктам стороннього запаху, не вбирає вологу та інші рідини. Така фольга також $є$ жиростійкою і морозостійкою, не накопичує статичних зарядів і за товщини більше 25 мкм $\epsilon$ практично непроникною для газів, рідин і світла [5]. Тому при використанні алюмінієвої фольги, термін зберігання запакованих продуктів може бути збільшено у декілька разів, при повному збереженні органолептичних показників.

Перспективним $€$ нанесення наночастинок $\mathrm{ZnO} / \mathrm{SiO}_{2}$ у складі фарбових композицій на поверхні пакувальних матеріалів друкарськими методами, що дозволяє швидко та економічно вигідно виготовляти розумні паковання у промислових масштабах. Оскільки специфікою люмінесцентних фарб є необхідність ï нанесення на матеріали відносно товстими шарами, то доцільно застосовувати для виготовлення нанофотонних маркувань трафаретний спосіб друку, який дає можливість одержува- ти товщину фарбового шару на відбитку до 100 мкм і більше [6], а у випадку використання ротаційного трафаретного друку швидкість виготовлення маркувань $€$ прийнятною для промислового виробництва.

Однак при використанні трафаретного друку необхідно враховувати вплив технологічних факторів на оптичні властивості одержуваних друкованих маркувань, а саме інтенсивність і колір люмінесценції, 3 метою виготовлення маркувань із наперед заданими оптичними властивостями. Тому актуальними є дослідження процесів нанесення композицій на основі наночастинок $\mathrm{ZnO} / \mathrm{SiO}_{2}$ на алюмінієву фольгу трафаретним способом друку.

\section{Аналіз попередніх досліджень}

Було проаналізовано широкий спектр літературних джерел і на цей момент виявлено, що питання впливу технологічних факторів трафаретного способу друку на оптичні властивості друкованих зображень з нанофотонними елементами при друці на фользі $€$ недостатньо розкритим. Існують дослідження складу фарб з нанофотонними елементами $[7,8]$ та технологічні аспекти виготовлення зображень 3 нанофотонними елементами друкарськими методами на паперових і плівкових пакувальних матеріалах [9, 10]. 3 огляду на вищесказане, необхідними є дослідження процесів нанесення композицій на основі наночастинок $\mathrm{ZnO} / \mathrm{SiO}_{2}$ на алюмінієву фольгу трафаретним способом друку, з метою визна- 
чення впливу технологічних факторів на оптичні властивості одержуваного фарбового шару на відбитку, що уможливить виготовлення маркувань розумних паковань з наперед заданими оптичними властивостями.

\section{Мета роботи}

Визначення впливу технологічних факторів на оптичні властивості маркувань $з$ нанофотонними елементами при нанесенні на алюмінієву фольгу трафаретним способом друку.

\section{Результати проведених досліджень}

Було розроблено склад композиції для друкування, яка містить 0,15\% наночастинок оксиду цинку $(\mathrm{ZnO}), 10$ \% нанорозмірного діоксиду кремнію $\left(\mathrm{SiO}_{2}\right)$ і 12 \% полівінілпіролідону (ПВП) $\mathrm{M}=360000$ г/моль у спиртовому розчині. $\mathrm{SiO}_{2}$ вводили для покращення люмінесцентних властивостей та агрегаційної стабільності люмінофора. Використання ПВП дозволяє досягти технологічно необхідної в'язкості для здійснення трафаретного друку.

Етанольні розчини наночастинок $\mathrm{ZnO} / \mathrm{SiO}_{2}$ одержували за методикою, наведеною в [3]. Наважки ретельно розтертих, безводних $\mathrm{Zn}\left(\mathrm{CH}_{3} \mathrm{COO}\right)_{2}$ і $\mathrm{NaOH}$ розчиняли окремо в абсолютному етанолі. Наважку діоксиду кремнію диспергували в етанольному розчині $\mathrm{Zn}\left(\mathrm{CH}_{3} \mathrm{COO}\right)_{2}$ після його повного розчинення. Відповідні розчини ацетату і лугу охолоджували до $0^{\circ} \mathrm{C}$ і повільно змішували при інтенсивному перемішуванні шляхом додавання розчину $\mathrm{NaOH}$ до розчину
$\mathrm{Zn}\left(\mathrm{CH}_{3} \mathrm{COO}\right)_{2}$ з $\mathrm{SiO}_{2}$. Після змішування реагентів колоїди витримували при 60 С протягом двох годин. Концентрація нанокристалів оксиду цинку після синтезу складає $2 \cdot 10^{-2}$ моль/л.

ПВП М = 360000 г/моль у вигляді порошку додавали до етанольних розчинів наночастинок $\mathrm{ZnO} / \mathrm{SiO}_{2}$ невеликими порціями при перемішуванні на магнітній мішалці до повного розчинення ПВП. Попередньо було встановлено, що введення наночастинок $\mathrm{ZnO} / \mathrm{SiO}_{2}$ в полімерні плівки ПВП не приводить до суттєвих змін люмінесцентних властивостей вихідних люмінофорів [7].

Спектри фотолюмінесценції, за якими визначали інтегральну інтенсивність люмінесценції відбитків, було записано за допомогою флуоресцентного спектрометра Perkin Elmer LS 55, за однакових умов вимірювань довжина хвилі світла збудження люмінесценції $\lambda_{\text {збудж. }}=330 \mathrm{HM}$, оптична ширина щілин 15 нм і 2,5 нм, емісійний фільтр при 390 нм.

Було здійснено нанесення трафаретним друком фарбових композицій на:

1) глянцеву (шорсткість якої, за даними виробника, характеризується середнім арифметичним відхиленням профілю $\mathrm{R}_{\mathrm{a}}=$ $=0,3$ мкм) та матову $\left(R_{a}=0,7\right.$ мкм $)$ поверхні алюмінієвої фольги;

2) у 1, 2, 3 і 4 шари для варіювання товщини фарбового шару на відбитку;

3) $з$ вмістом люмінесцентної складової (наночастинок ZnO) $0,15 \%, 0,1 \%$ та 0,05\%.

Кожен наступний шар фарби наносився на відбиток після повного висихання попереднього шару, тобто відбувався друк «по сухому». 
Товщина шару фарби на відбитку при використанні трафаретного друку залежить від багатьох параметрів: жорсткості і параметрів кромки ракеля, куту нахилу ракеля, тиску ракеля на сітку, параметрів сітки, величини технологічного зазору (відстань між сіткою і задруковуваним матеріалом), швидкості друкування, в'язкості фарби і т. д. При півавтоматичному і автоматичному трафаретному друці цю товщину можна досить точно встановити шляхом встановлення відповідних технологічних факторів. Питанням досягнення необхідної товщини фарбового шару у трафаретному друці присвячено багато наукових праць. Тому в даному дослідженні вказується кінцева товщина шару фарби на відбитку, без прив'язки до величин технологічних факторів, які впливають на її досягнення і визначаються в кожному конкретному випадку для конкретного обладнання на даному поліграфічному підприємстві.

Товщина фарбових шарів була розрахована ваговим мето- дом і складала: для 1 шару -

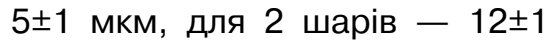
мкм, для 3 шарів - 18 \pm 2 мкм,

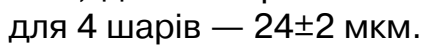

Було обрано два типи алюмінієвої фольги, які є найбільш поширеними при виробництві паковань. Фольга як задруковуваний матеріал подібно до поліпропіленової плівки не є вбирним (не всотує розчинник фарби), та має однаковий ряд товщин, але різну за оптичними властивостями і структурою поверхню. Під час виготовлення алюмінієвої фольги, при проходженні між каландрувальними циліндрами фольга складається навпіл - одна її сторона дотикається до поверхні каландрувального циліндра, а інша знаходиться всередині і дотикається лише до поверхні фольги. Глянцева поверхня фольги обумовлена прямим контактом 3 каландрувальним циліндром при виготовленні фольги, а матова - відсутністю такого контакту. Відповідно, різними $€$ шорсткість поверхні і оптичні характеристики матової і глянцевої поверхні фольги.

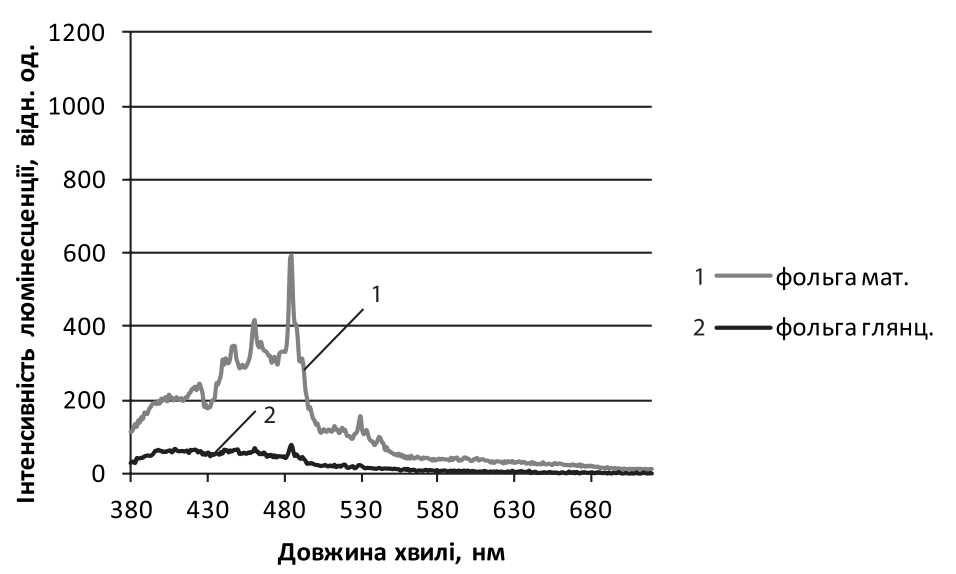

Рис. 1. Спектри люмінесценції матової і глянцевої поверхні фольги 
На рис. 1 наведено спектри люмінесценції матової і глянцевої поверхні фольги.

Як видно 3 рис. 1, матова поверхня фольги має більш виражену люмінесценцію. Поява люмінесценції матової сторони може бути обумовлена як люмінесценцією оксиду алюмінію [11], формування якого на матовій стороні більш виражене, так і люмінесценцією сорбованих на поверхні органічних домішок, які могли утворитися в процесі виготовлення фольги.

На рис. 2-4 наведені спектри люмінесценції нанесених трафаретним друком композицій на алюмінієву фольгу за різної

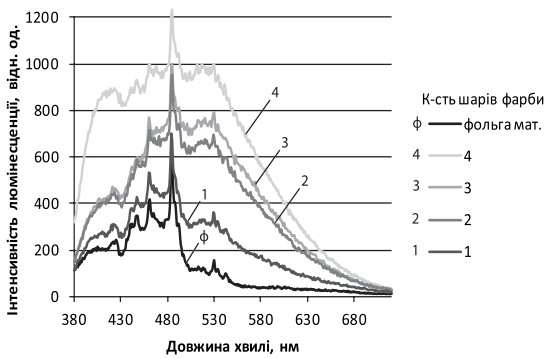

a концентрації люмінесцентної складової у фарбовій композиції.

При попарному порівнянні рис. 2-4, а і б помічено, що інтенсивність люмінесценції зразків, надрукованих на фольгу, більша на матовій стороні і менша на глянцевій стороні фольги для кожної концентрації люмінесцентної складової: максимальної $(0,15 \%$, рис. 2), середньої $(0,1 \%$, рис. 3$)$ і мінімальної (0,05 \%, рис. 4). Це обумовлено відповідним впливом власної люмінесценції фольги, інтенсивність якої більша на матовій стороні і менша на глянцевій (див. рис. 1).

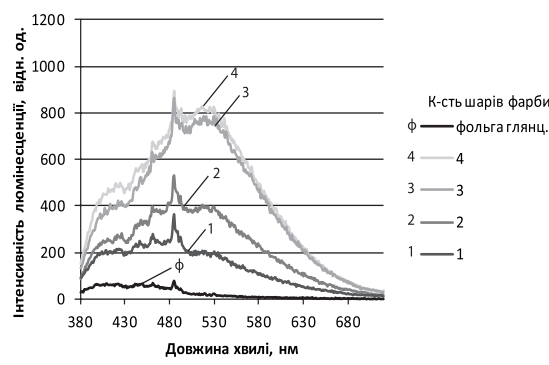

б

Рис. 2. Спектри люмінесценції нанесених трафаретним друком композицій на алюмінієву фольгу. Поверхня фольги: а - матова, б - глянцева.

Концентрація люмінесцентної складової 0,15\%

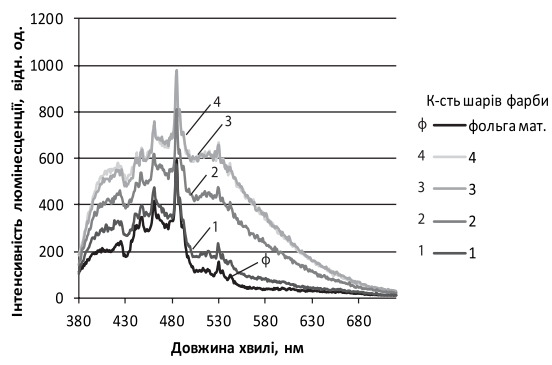

a

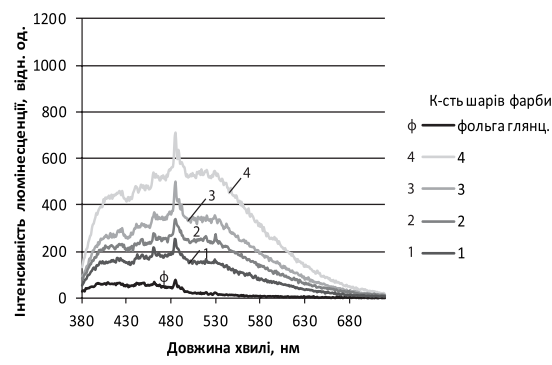

6

Рис. 3. Спектри люмінесценції нанесених трафаретним друком композицій на алюмінієву фольгу. Поверхня фольги: а - матова, б - глянцева. Концентрація люмінесцентної складової 0,1% 

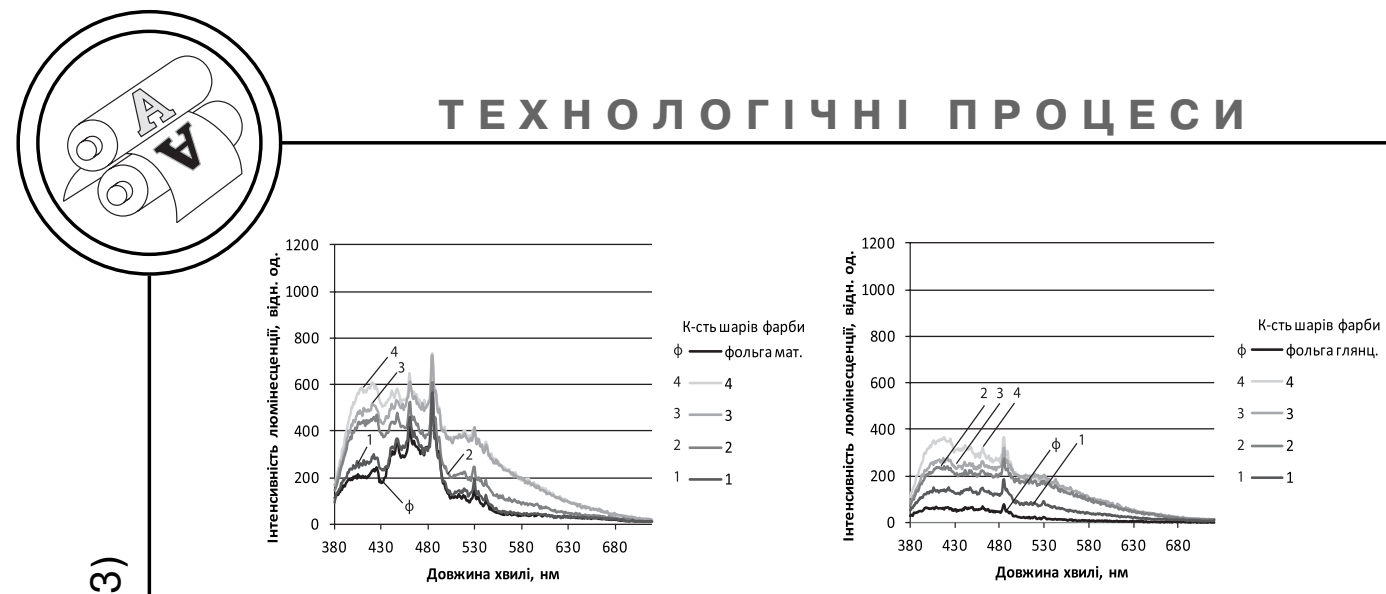

a

б

Рис. 4. Спектри люмінесценції нанесених трафаретним друком композицій на алюмінієву фольгу. Поверхня фольги: а - матова, б - глянцева. Концентрація люмінесцентної складової 0,05 \%

3 рис. 2 видно, що при максимальних концентраціях люмінесцентної складової у композиції можна одержати:

1. На матовій поверхні фольги (рис. 2, а) - люмінесценцію 3 деяким переважанням величини піку у середньохвильовій області спектру над піком у короткохвильовій області спектру, що відповідає синьо-зеленому кольору люмінесцентного випромінювання. Причому при збільшенні товщини шару фарби на відбитку частка синьої складової зменшується і колір люмінесценції зеленого відтінку.

2. На глянцевій поверхні фольги (рис. 2, б) - люмінесценцію 3 значним переважанням піку у середньохвильовій області спектру ( $\lambda=520$ нм) над піком у короткохвильовій області спектру ( $\lambda=430$ нм), що відповідає зелено-жовтому кольору люмінесцентного випромінювання. Причому при збільшенні товщини шару фарби на відбитку частка синьої складової зменшується і колір люмінесценції жовтого відтінку.

3 рис. 3 видно, що для середнього вмісту люмінесцентної складової у фарбовій композиції (концентрація наночастинок ZnO $0,1 \%)$, відбуваються аналогічні зміни кольору люмінесценції, але при цьому частка випромінювання в середньохвильовій області спектру ( $\lambda=520$ нм) $€$ меншою, ніж у попередньому випадку. Тобто в спектрі люмінесценції відбитків пік у середньохвильовій незначно переважає над піком у короткохвильовій області, що відповідає зеленому кольору люмінесцентного випромінювання. Причому при невеликій товщині шару фарби (1-2 шари) на відбитку частка короткохвильової складової у спектрі перевищує і колір люмінесценції набуває більше синього відтінку.

3 рис. 4 видно, що для найменшого вмісту люмінесцентної складової у фарбовій композиції (концентрація наночастинок ZnO 0,05 \%), пік випромінювання в середньохвильовій області спектру $(\lambda=520$ нм $) €$ завжди меншим, ніж у короткохвильовій області ( $\lambda=430$ нм), що відповідає синьому кольору люмінесцентного випромінювання, незалежно від товщині шару фарби на відбитку. 
Загалом товщина шару фарби на відбитку впливає на інтенсивність люмінесценції.

Для більш детального вивчення цих явищ було розраховано спектри власної люмінесценції фарбових композицій з наночастинками оксиду цинку на алюмінієвій фользі, одержані шляхом віднімання інтенсивностей люмінесценції задрукованих ділянок від інтенсивностей люмінесценції відповідного матеріалу в незадрукованих ділянках. Вони наведені на рис. 5-7.

Як видно з рис. 5-7, власна люмінесценція друкованих шарів на матовій і на глянцевій поверхні фольги відрізняється

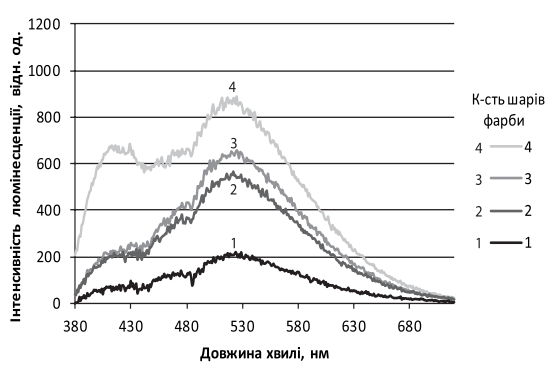

a як за формою, так і за величиною. Інтенсивність власної люмінесценції зразків на матовій стороні фольги є дещо вищою, ніж на глянцевій. Спектри власної люмінесценції зразків на матовій стороні фольги містять більш виражений пік у короткохвильовій області спектру при 400 нм, характерний для ПВП, тоді як спектри власної люмінесценції зразків на глянцевій стороні фольги містять менш виражений пік при 400 нм. Це означає, як було видно і з рис. 2-4, що на матовій фользі колір люмінесценції зразків загалом має більш синій відтінок.

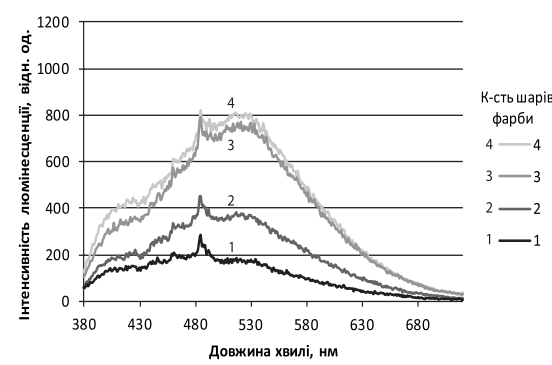

б

Рис. 5. Спектри власної люмінесценції нанесених трафаретним друком композицій на алюмінієву фольгу. Поверхня фольги: а - матова, б глянцева. Концентрація люмінесцентної складової 0,15 \%

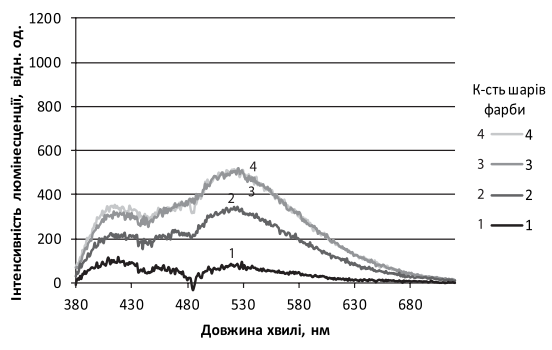

a

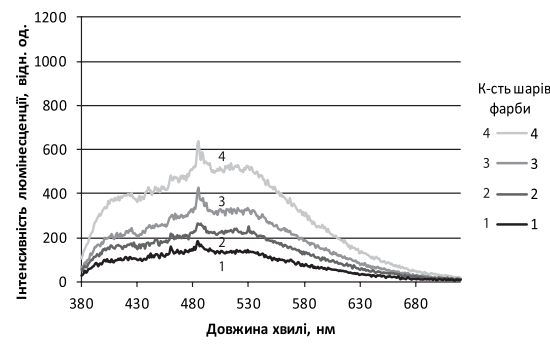

б

Рис. 6. Спектри власної люмінесценції нанесених трафаретним друком композицій на алюмінієву фольгу. Поверхня фольги: а - матова, б глянцева. Концентрація люмінесцентної складової 0,1% 


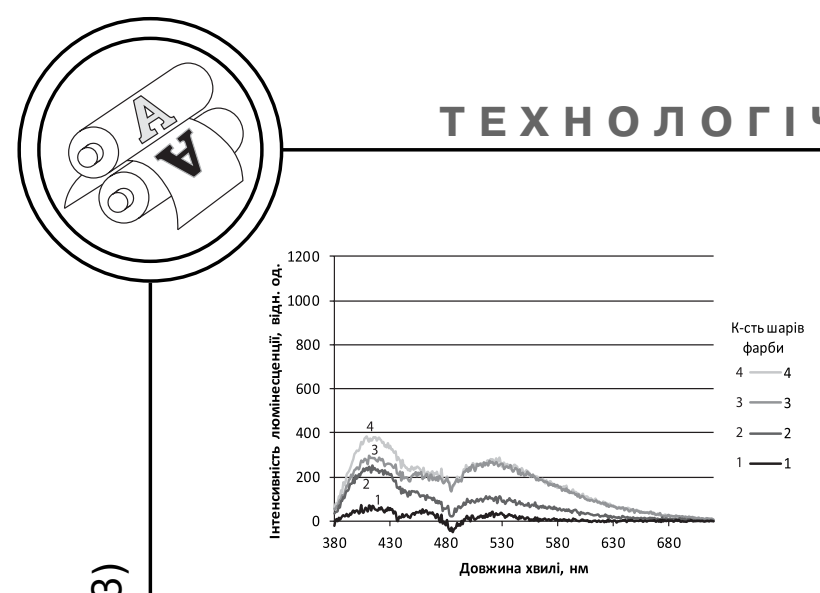

a

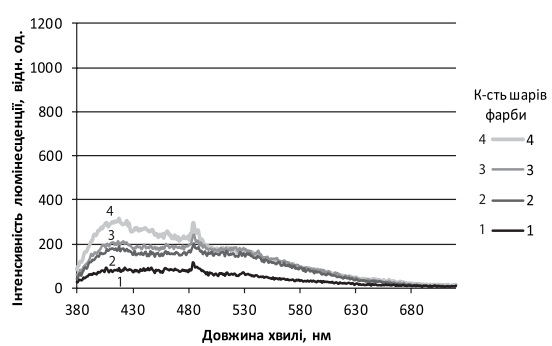

б

Рис. 7. Спектри власної люмінесценції нанесених трафаретним друком композицій на алюмінієву фольгу. Поверхня фольги: а - матова, б глянцева. Концентрація люмінесцентної складової 0,05 \%

На рис. 8 зведено вищенаведені дані про інтенсивності люмінесценції друкованих зразків на фользі у вигляді залежностей інтенсивності люмінесценції від кількості шарів фарби на відбитку.

Аналогічно здійснено порівняння даних про власні інтенсивності люмінесценції друкованих зразків на фользі у вигляді залежностей власної інтенсивності люмінесценції від кількості шарів фарби на відбитку.

Як видно з рис. 9, при максимальній концентрації люмінесцентної складової $(0,15 \%)$ у фарбовій композиції і на матовій, і на глянцевій поверхні фольги досягаються майже однакові інтенсивності власної люмінесценції, тоді як при менших концентраціях люмінесцентної складової у фарбовій композиції $(0,1 \%$ і $0,05 \%)$ на матовій поверхні фольги одержують більші інтенсивності власної люмінесценції, ніж на глянцевій поверхні.

Таким чином, виявлено, що для досягнення оптимальних показників інтенсивності люмінесценції маркувань (більше 200 відн. од.), за яких люмінесцентне зображення чітко сприймається оком людини при вико-

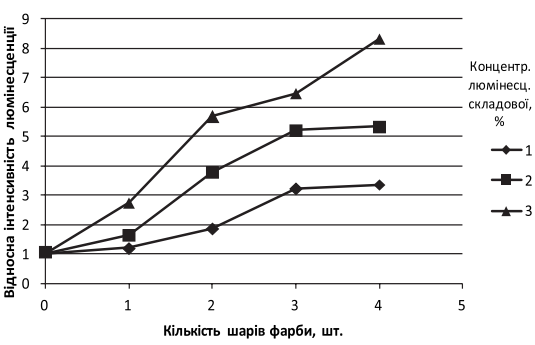

a

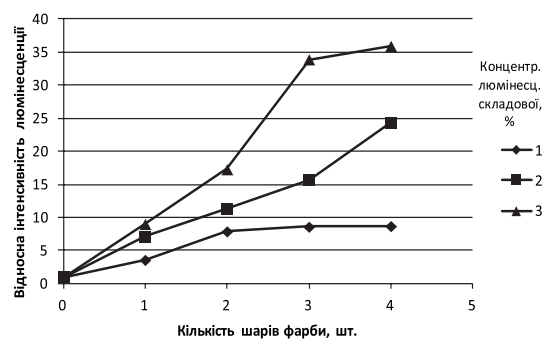

6

Рис. 8. Залежність інтенсивності люмінесценції друкованих зразків при довжині хвилі $=520$ нм на фользі від кількості шарів фарби на відбитку, для різних концентрацій люмінесцентної складової. Поверхня фольги: а - матова, б - глянцева 
ристанні найбільш поширених УФ ламп для перевірки банкнот, висуваються наступні рекомендації. При друці на глянцевій поверхні фольги слід одержувати друковані шари фарбовою композицією з вмістом люмінесцентної складової 0,15 \%, при цьому досягати товщину шару фарби на відбитку не менше 5 мкм; з вмістом люмінесцентної складової 0,1%не менше 12 мкм; з вмістом люмінесцентної складової 0,05 \% не менше 18 мкм. При друці на матовій поверхні фольги слід одержувати друковані шари фарбовими композиціями з вмістом люмінесцентної складової не менше 0,1\%, при цьому досягати товщину шару фарби на відбитку не менше 12 мкм. При цьому для одержання синього кольору люмінесценції маркувань слід здійснювати друкування на матовій фользі, а зеленого і жовто-зеленого - на глянцевій.

\section{Висновки}

Було досліджено вплив факторів технологічного процесу друкування трафаретним спо- собом друку на оптичні характеристики одержуваних друкованих зображень 3 нанофотонними елементами на алюмінієвій фользі для розумних паковань. Було визначено, яким чином обрати поверхню алюмінієвої фольги, концентрацію люмінесцентної складової і товщину шару фарби на відбитку, щоб одержати сині, зелені і жовті відтінки люмінесценції певної інтенсивності у друкованих відбитків, отриманих з використанням фарб 3 наночастинками $\mathrm{ZnO} / \mathrm{SiO}_{2}$. Досліджені явища можна використовувати для прогнозування одержуваної інтенсивності люмінесценції зображень, надрукованих трафаретним друком фарбовими композиціями 3 нанофотонними елементами на поверхні алюмінієвої фольги як пакувального матеріалу, залежно від технологічних параметрів, а також $з$ метою варіювання кольору люмінесценції.

Дослідження проводилися за підтримки Міністерства освіти і науки України в рамках НДР № 2873п. Публікація містить результати досліджень, проведених

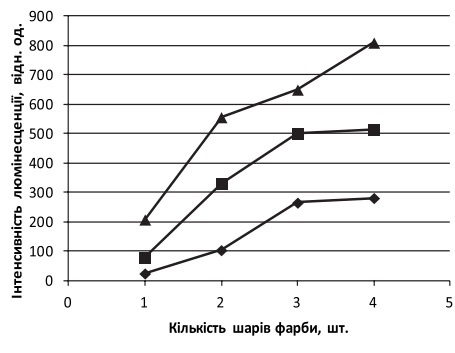

a
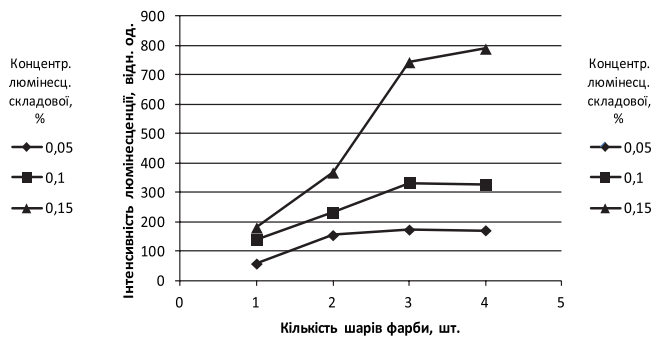

б

Рис. 9. Залежність власної інтенсивності люмінесценції друкованих зразків при довжині хвилі $\lambda=520$ нм на фользі від кількості шарів фарби на відбитку, для різних концентрацій люмінесцентної складової.

Поверхня фольги: а - матова, б - глянцева 
при грантовій підтримці Державного фонду фундаментальних

досліджень за конкурсним проектом Ф64/10-2016 від 28.03.16.

\section{Список використаної літератури}

1. Sekhon B. S. Food nanotechnology - an overview / B. S. Sekhon // Nanotechnology, Science and Applications. - 2010. - Vol. 3. - P. 15.

2. Yam K. L. Intelligent packaging: concepts and applications / K. L. Yam, P. T. Takhistov, J. Miltz // Journal of food science. - 2005. - Vol. 70(1). - P. 10.

3. Shvalagin V. Influence of nanosized silicon oxide on the luminescent properties of ZnO nanoparticles / V. Shvalagin, G. Grodziuk, O. Sarapulova, M. Kurmach, V. Granchak, V. Sherstiuk // Journal of Nanotechnology. - 2016. Vol. 2016. - P. 1-7.

4. Sarapulova O. Luminescent nanosized composites for indicating and preventing compositional changes of packaged products in modern printed packaging / O. Sarapulova, V. Sherstiuk, V. Shvalagin // Nanoscience and Nanotechnology Letters. - 2013. - Vol. 5. - P. 1141-1146.

5. Фізико-хімічні властивості пакувальних матеріалів : навч. посібник / Костюк В. С., Соколенко А. І., Васильківський К. В. та ін. / За ред. Соколенка А. І. - К. : Кондор-Видавництво. - 2013. - 402 с.

6. Ткачук М. П. Трафаретний друк / М. П. Ткачук. - К. : ХаГар, 2000. $264 \mathrm{c}$.

7. Шерстюк В. П. Люминесцентные пленки на основе наноразмерного оксида цинка в поливинилпирролидоне и их функциональные характеристики / В. П. Шерстюк, В.В.Швалагин, О. О. Сарапулова, В. М. Гранчак // VI Международная научная конференция «Функциональная база наноэлектроники». Сборник научных трудов. - Харьков : ХНУРЭ, 2013. - 393 с. - С. 250-253.

8. Сарапулова О. О. Проблеми поліграфічного виготовлення новітніх паковань 3 нанорозмірними фотоактивними елементами / О. О. Сарапулова, В. П. Шерстюк // Технологія і техніка друкарства. - 2013. - № 2. - С. 46-57. - Режим доступу : http://ttdruk.vpi.kpi.ua/article/view/30734.

9. Сарапулова О. О. Технологічні особливості нанесення нанофотонних елементів паковань трафаретним способом друку / О. О. Сарапулова, В. П. Шерстюк // Технологія і техніка друкарства. - 2013. - № 3. - С. 18-26. Режим доступу : http://ttdruk.vpi.kpi.ua/article/view/23515.

10. Сарапулова О. Особливості відтворення нанофотонних міток тампонним способом друку / О. Сарапулова, В. Шерстюк // Матеріали доповідей XVIII Міжнародної науково-практичної конференції з проблем видавничо-поліграфічної галузі. - 2014. - С. 56-58.

11. Люминесценция пленок оксида алюминия и перспективы их использования в планарных микроструктурах нанофотоники / [Л. С. Хорошко, Т. И. Ореховская, М. В. Меледина, И. А. Николаенко, А. С. Кочев, А. М. Ашариф, Б. С. Колосницын, Н. В. Гапоненко, А. В. Мудрый] // Доклады БГУИР. 2012. - № 5(67). - С. 16-20.

\section{References}

1. Sekhon, B. S. (2010). Food nanotechnology - an overview. Journal of Nanotechnology, Science and Applications, vol. 3, 15 [in English]. 
2. Yam, K. L. \& Takhistov, P. T. \& Miltz, J. (2005). Intelligent packaging: concepts and applications. Journal of food science, vol. 70(1), 10 [in English].

3. Shvalagin, V. \& Grodziuk, G. \& Sarapulova O., \& Kurmach, M. \& Granchak, V. \& Sherstiuk, V. (2016). Influence of nanosized silicon oxide on the luminescent properties of ZnO nanoparticles. Journal of Nanotechnology, vol. 2016, 1-7 [in English].

4. Sarapulova, O. \& Sherstiuk, V. \& Shvalagin, V. (2013). Luminescent nanosized composites for indicating and preventing compositional changes of packaged products in modern printed packaging. Journal of Nanoscience and Nanotechnology Letters, vol. 5, 1141-1146 [in English].

5. Kostiuk, V. S. \& Sokolenko, A. I. \& Vasylkivskyi, K. V. (2013). Fizyko-khimichni vlastyvosti pakuvalnykh materialiv [Physico-chemical properties of packaging materials]. Kyiv: Kondor-Vydavnytstvo [in Ukrainian].

6. Tkachuk, M. P. (2000). Trafaretnyi druk [Screen printing]. Kyiv: KhaHar [in Ukrainian].

7. Sherstjuk, V. P. \& Shvalagin, V. V. \& Sarapulova, O. O. \& Granchak, V. M. (2013). Ljuminescentnye plenki na osnove nanorazmernogo oksida cinka $v$ polivinilpirrolidone i ih funkcional'nye harakteristiki [Fluorescent films based on nanosized zinc oxide in polyvinylpyrrolidone and their functional characteristics]. Journal of Funkcional'naja baza nanojelektroniki. - Functional base of nanoelectronics. Har'kov: HNURJe [in Russian].

8. Sarapulova, O. O. \& Sherstiuk, V. P. (2013). Problemy polihrafichnoho vyhotovlennia novitnikh pakovan z nanorozmirnymy fotoaktyvnymy elementamy [Issues of printing production of modern packaging with nanosized photoactive elements]. Journal of Tekhnolohiia i tekhnika drukarstva. - Technology and Technique of Typography, 2, 46-57. Retrieved from http://ttdruk.vpi.kpi.ua/ article/view/30734 [in Ukrainian].

9. Sarapulova, O. O. \& Sherstiuk, V. P. (2013). Tekhnolohichni osoblyvosti nanesennia nanofotonnykh elementiv pakovan trafaretnym sposobom druku [Technological features of application of nanophotonic elements of packaging by screen printing]. Journal of Tekhnolohiia i tekhnika drukarstva. - Technology and Technique of Typography, 3, 18-26. Retrieved from http://ttdruk.vpi. kpi.ua/article/view/23515 [in Ukrainian].

10. Sarapulova, O. \& Sherstiuk, V. (2014). Osoblyvosti vidtvorennia nanofotonnykh mitok tamponnym sposobom druku [Features reproduction of nanophotonic label of pad printing]. Journal of Problemy vydavnycho-polihrafichnoi haluzi. - Problems publishing and printing industry, 56-58 [in Ukrainian].

11. Horoshko, L. S. \& Orehovskaja, T. I. \& Meledina, M. V. \& Nikolaenko, I. A. \& Kochev, A. C. \& Asharif, A. M. \& Kolosnicyn, B. S. \& Gaponenko, N. V. \& Mudryj, A. V. (2012). Ljuminescencija plenok oksida aljuminija i perspektivy in ispol'zovanija $v$ planarnyh mikrostrukturah nanofotoniki [Luminescence of oxide films aluminum and prospects of their use in planar microstructures nanophotonics]. Journal of Doklady BGUIR. - Reports of BSUIR, 5(67), 16-20 [in Russian]. 
способом печати на алюминиевую фольгу как перспективный упаковочный материал. Определено влияние поверхностных характеристик алюминиевой фольги, толщины слоя краски на оттиске и содержания люминесцентной составляющей на оптические характеристики получаемых печатных маркировок, что дает возможность изготавливать маркировки умных упаковок с нанофотонными элементами с наперед заданными оптическими характеристиками трафаретным способом печати.

Ключевые слова: трафаретная печать; фотолюминесценция; умная упаковка; нанофотонные элементы; наночастички ZnO.

In this article, the possibility of applying markings of smart packaging with nanophotonic elements by screen printing on aluminum foil as a perspective packaging material is studied. The influence of surface characteristics of aluminum foil, ink thickness on a printed impression and content of a fluorescent component on optical characteristics of the obtained printed labels is determined, which makes it possible to produce markings for smart packaging with nanophotonic elements with predetermined optical characteristics by screen printing.

Keywords: screen printing; photoluminescence; smart packaging; nanophotonic elements; ZnO nanoparticles. 